\title{
Health Check-up of Commercial Banks in the Framework of CAMEL: A Case Study of Joint Venture Banks in Nepal
}

\author{
Keshar J. Baral
}

\begin{abstract}
Using the data set published by joint venture banks in their annual reports, and NRB in its supervision annual reports, this paper examines the financial health of joint venture banks in the CAMEL framework. The health check up conducted on the basis of publicly available financial data concludes that the health of joint venture banks is better than that of the other commercial banks. In addition, the perusal of indicators of different components of CAMEL indicates that the financial health of joint venture banks are not so strong to manage the possible large scale shocks to their balance sheet and their health is fair.
\end{abstract}

THE HISTORY OF MODERN commercial banking industry dates back to 1937 A.D in which year Nepal Bank Ltd. was incorporated. Till 1984, financial sector was closed to private sector and foreign investors. HMG/Nepal started to liberalize the financial sector in the first half of the 1980s. But it speeded up this process only in early 1990s. Private sector rushed into the finance industries especially after the restoration of democracy in 1990 . Most of the commercial banks came into operation during the decade of 1990s. Government of any countries highly monitors and controls the finance industry even in the liberalized market economy. Government does so due to its high gravity in the national economy, and to build up the confidence of private sector in its financial system. Nepal Rastra Bank (NRB) as an apex monetary authority of the country started to monitor and control the finance industry especially at the end of the 1990s by issuing the directives to the financial institutions (FIs). It initiated the offsite and onsite supervision of FIs to maintain their sound financial health and to build up the confidence of private sector in the liberalized financial system and protect the interest of the investors. It has adopted the CAEL (capital adequacy, asset quality, earning and liquidity) system to check up the health of FIs. It has yet to use the CAMELS to evaluate the financial performance and check up the financial health. Independent outsiders also can not use all components of CAMELS to check up the financial health of FIs in Nepal due to the full disclosures of required financial information to outsiders. NRB dictated FIs to disclose the financial information in uniform way only in the fiscal year (FY) 2001/02. In this paper, attempt has been made to check up the financial health of joint venture banks in the framework of CAMEL.

\section{Rationale of Regular Health Check up of Commercial Banks}

Not only the commercial banks but also any FIs require regular health check up to maintain the confidence of private sector in financial system of the country and protect the interest of depositors, lenders, shareholders and other stakeholders. The gravity of the importance of sound financial sector has increased tremendously after the international financial turmoil of the second half of the 1990s. International monetary authorities such as International Monetary Fund and international FI like the World Bank have underpinned the need of healthy financial sector to build up the confidence of private sector in the liber- 


\section{The Journal of Nepalese Business Studies}

alized financial system. Therefore, they have directed their member countries to reform the financial sector and conduct the regular health check up of FIs through onsite and offsite supervision. International FIs like the World Bank and Asian Development Bank (ADB) are supporting the projects run in the vein of reforming process of the financial sector of different countries. For example, the World Bank is constantly providing the technical and financial support to reengineer NRB and restructure Nepal Bank Ltd. and Rastriya Banijya Bank (NRB 2005).

Health of financial sector depends on the health of individual FIs. In addition, individual FI's health counts on the myriad macro and micro factors. Among the macro factors, political stability and the real sector growth are vital. The financial health of FIs can not sustain without the political stability and sustainable real sector growth with sound health. However, the intensity of contagious effect of these macro variables may vary from one individual FI to another. Therefore, health of individual FI should be checked up regularly to know the intensity of such effect.

Health of an individual FI is a function of multiple factors such as quality of its assets, liquidity position, capital base, management quality, market sensitivity and earnings. All these factors affect the different types of risk to an individual FI. Different types of risks: credit risk, interest rate risk, liquidity risk, market risk, off-balance sheet risk, foreign exchange risk, sovereign risk, technology, operational risk, insolvency risk, affect the health of an individual FI adversely if they are not managed in sustainable manner (Saunders and Cornett 2004). A number of factors such as quality of assets, financial market condition, foreign exchange market, composition of assets, financial health of its clients, profitability, capital adequacy, affect the degree of these risks. Financial health check-up of an individual institution should be made regularly to detect the adverse effect of these risks on its health. Micro-prudential indicators such as capital adequacy, asset quality, management soundness, earning and profitability, liquidity, sensitivity to market risk, and market based indicators like market price of financial instruments, credit ratings are used as indicators of the sound health of an individual FI (Evan and others 2000). These indicators are explained at length in the ensuing section of this paper.

\section{Theoretical Prescription of CAMELS Framework}

The Basle Committee on Banking Supervision of the Bank of International Settlements (BIS) has recommended using capital adequacy, assets quality, management quality, earnings and liquidity (CAMEL) as criteria for assessing a FI in 1988 (ADB 2002). The sixth component, market risk (S) was added to CAMEL in 1997 (Gilbert, Meyer and Vaughan 2000). However, most of the developing countries are using CAMEL instead of CAMELS in the performance evaluation of the FIs. The central banks in some of the countries like Nepal, Kenya use CAEL instead of CAMELS.

CAMELS framework is a common method for evaluating the soundness of FIs. This system was developed by regulatory authorities of the U.S banks. The Federal Reserve Bank, the Comptroller of the Currency and the Federal Deposit Insurance Corporation all use this system (McNally 1996). Monetary authorities in the most of the countries are using this system to check up the health of an individual FI. In addition, International Monetary Fund also is using the aggregated indicators of individual FIs to assess the financial system 
soundness of its member countries as part of its surveillance work (Hilbers, Krueger and Moretti 2000).

\subsection{Capital Adequacy}

CAMELS framework system looks at six major aspects of an FI: capital adequacy, asset quality, management soundness, earnings, liquidity, and sensitivity to market risk (Hilbers, Krueger and Moretti 2000). The first component, capital adequacy ultimately determines how well FIs can manage with shocks to their balance sheets. Thus, it tracks capital adequacy ratios that take into account the most important financial risks-foreign exchange, credit, and interest rate risks - by assigning risk weightings to the institution's assets. For the purpose of capital adequacy measurement, bank capital is divided into Tier I and Tier II. Tier I capital is primary capital and Tier II capital is supplementary capital. In Nepalese context, Tier I (core/primary) capital includes paid-up capital, share premium, non-redeemable preference share, general reserve fund, accumulated profit, capital redemption reserve, capital adjustment fund, and other free reserve. Amount of the goodwill, fictitious assets, investment in the financial instruments issued by an organized organization in excess to the limit specified by NRB, and investment in the financial instruments issued by the organizations having the own financial interest is deducted from the sum of all elements of the primary capital to arrive at the core capital. Similarly, Tier II (supplementary) capital comprises of general loan loss provision, assets revaluation reserve, hybrid capital instruments, subordinated term loan, exchange equalization reserve, excess loan loss provision, and investment adjustment reserve. Thus, the total capital of commercial banks is the sum of core capital and supplementary capital (NRB 2005).

Leverage ratio can be used to measure the capital adequacy of a bank. This is the ratio of bank's book value of core capital to the book value of its assets. The higher ratio shows the higher level of capital adequacy. The U.S.A. Federal Deposit Insurance Corporation Improvement Act (FDICIA) of 1991 has fixed the five target zones: i. 5 percent and above ii. 4 percent and above iii. under 4 percent, iv. under 3 percent, v. 2 percent and less, of leverage ratio. The leverage ratio falling in the first zone implies that bank is well capitalized. Similarly, the leverage falling in the second zone shows that bank is adequately capitalized. The leverage falling in the last three zones indicates that bank is inadequately capitalized and regulators should take prompt corrective action to bring the capital to the desirable level (Saunders and Cornett 2004).

The leverage ratio stated in the foregoing discussion is simple capital to assets ratio. In other words, assets are not risk adjusted. The 1993 Basel Accord enforced the capital ratio to risk adjusted assets of commercial banks. According to this accord, core capital must equal to or exceed 4 percent of the risk weighted assets of the commercial banks. Similarly, the amount of the supplementary capital should not exceed the amount of the core capital and the total capital must equal or exceed 8 percent of risk weighted assets (Saunders and Cornett 2004). NRB initially fixed the core capital at the level of 4.5 percent of the risk weighted assets and total capital at the level of 9 percent of risk weighted assets of the commercial banks (NRB 2058). For the current FY2005/06, the mandatory levels of core capital and total capital are 6 percent and 12 percent of risk weighted assets of commercial banks. But NRB has strictly directed all commercial banks that the amount of the supplementary capital should not be in excess to the amount of the core capital (NRB 2005). 


\subsection{Asset Quality}

Credit risk is one of the factors that affect the health of an individual FI. The extent of the credit risk depends on the quality of assets held by an individual FI. The quality of assets held by an FI depends on exposure to specific risks, trends in non-performing loans, and the health and profitability of bank borrowers-especially the corporate sector. We can use a number of measures to indicate the quality of assets held by FIs. ADB suggests these measures-loan concentration by industry, region, borrower and portfolio quality; related party policies and exposure on outstanding loan, approval process of loan, check and balance of loans; loan loss provision ratio; portfolio in arrear; loan loss ratio; and reserve ratio-of checking the quality of assets of an FI (ADB 2002).

NRB uses composition of assets, nonperforming loan to total loan ratio, net nonperforming loan to total loan ratio as the indicators of the quality of assets of commercial banks (NRB 2005. NRB has directed the commercial banks in regards to the concentration of the loan. Any licensed FI can grant the fund base loan to a single borrower or borrowers related to the same business group up to the 25 percent of its primary capital. In the same vein, it can provide the non-fund base loan up to 50 percent of its core capital (NRB 2005). Similarly, it has directed FIs to classify the loans into performing loan and nonperforming loans. The loans that are not due and 3 months past due fall in the class of performing loans/performing assets and others do in the non-performing loans. Further, non-performing loans are classified into three groups: substandard, doubtful, and bad debt/ loss (for detail classification see NRB directive 2/061/62).

Commercial banks have to make 1 percent provision for pass loan/performing loan, 25 percent for substandard loan, 50 percent for doubtful loan and 100 percent for bad loan (NRB 2005). Non-performing assets in the total assets of commercial banks was 22.77 percent in the FY 2003/04. But the percentage of non-performing assets of an individual commercial bank varies from 0.76 percent to 57.64 in the same fiscal year. But the normal international standard of the percentage of non-performing assets is 5-8 percent of the total assets.

\subsection{Management Quality}

Sound management is key to bank performance but is difficult to measure. It is primarily a qualitative factor applicable to individual institutions. Several indicators, however, can jointly serve as an indicator of management soundness. Expenses ratio, earning per employee, cost per loan, average loan size and cost per unit of money lent can be used as a proxy of the management quality. ADB recommends cost per unit of money lent as a proxy of management quality. But this can not be used as an indicator of management quality in Nepal. Since the data on amount of the total loan mobilized during a particular FY is not available in published financial statements and annual reports. As stated earlier, NRB has skipped up this component of CAMELS in the performance evaluation of commercial banks (see NRB 2005).

\subsection{Earning Performance}

Earning capacity or profitability keeps up the sound health of an FI. Chronically unprofitable FI risks insolvency on one hand and on the others, unusually high profitability can reflect excessive risk taking of an FI. There are different indicators of profitability. Return on assets, return on equity, interest-spread ratio, earning-spread ratio, gross margin, 
operating profit margin and net profit margin are commonly used profitability indicators. NRB uses return on total assets as an indicator of profitability of a commercial bank. In addition, it uses the absolute measures such as interest income, net interest income, noninterest income, net non-interest income, non-operating income, net non-operating income and net profit, to evaluate the profitability of a commercial bank (NRB 2005).

\subsection{Liquidity}

Liquidity risk threats the solvency of FIs. In the case of commercial banks, first type of liquidity risk arises when depositors of commercial banks seek to withdraw their money and the second type does when commitment holders want to exercise the commitments recorded off the balance sheet. Commercial banks have to borrow the additional funds or sell the assets at fire sale price to pay off the deposit liabilities. They become insolvent if sale price of the assets are not enough to meet the liability withdrawals. The second type of liquidity risk arises when demand for unexpected loans can not be met due to the lack of the funds. Commercial banks can raise the funds by running down their cash assets, borrowing additional funds in the money markets and selling off other assets at distressed price. Both liability side liquidity risk (first type risk) and asset side liquidity risk (second type risk) affect the health of commercial banks adversely. But maintaining the high liquidity position to minimize such risks also adversely affects the profitability of FIs. Return on highly liquid assets is almost zero. Therefore, FIs should strike the tradeoff between liquidity position and profitability so that they could maintain their health sound.

Commercial bank's liquidity exposure can be measured by analyzing the sources and uses of liquidity. In this approach, total net liquidity is worked out by deducting the total of uses of liquidity from the total of sources of liquidity. Similarly, BIS maturity laddering model can be used to measure the liquidity of a commercial banks. In addition, different liquidity exposure ratios such as borrowed funds to total assets, core deposit to total assets, loans to deposits, and commitments to lend to total assets are used to measure the liquidity position of a commercial bank (Saunders and Cornett 2004). NRB uses total loan to total deposit ratio, cash and equivalents to total assets ratio, cash and equivalents to total deposit ratio, NRB balance to total deposit ratio to measure the liquidity position of commercial banks in the course of the performance evaluation of commercial banks (NRB 2005).

\subsection{Sensitivity to Market Risk}

Commercial banks are increasingly involved in diversified operations such as lending and borrowing, transaction in foreign exchange, selling off assets pledged for securities and so on. All these are subject to market risk like interest rate risk, foreign exchange rate risk, and financial asset and commodity price risk. The health of an FI more sensitive to market risk is more hazardous than that of less sensitive. Foreign exchange risk, interest rate risk, equity price risk, and commodity price risk are the indicators of sensitivity to market risk.

\section{Methodology}

At present, all together 17 commercial banks are in operation. Out of this, Rastriya Banijya Bank is fully owned by HMG/Nepal while in case of Nepal Bank Ltd, HMG/Nepal is the major shareholder. There are six joint venture banks in collaboration with the foreign investment partners and remaining are fully owned by Nepalese investors. For the purpose 
of this study, the population has been defined in term of joint venture commercial banks. So the population of this study is six. For the purpose of this study, 3 banks-Nabil Bank Limited (Nabil), Nepal SBI Bank Ltd. (NSBI) and Standard Chartered Bank Nepal Limited $(\mathrm{SCBN})$, were selected randomly (for sampling frame and sample refer to Appendix 1).

This study is based on the historical data disclosed by annual reports of commercial banks. NRB has dictated the commercial banks to disclose the financial information in the prescribed format since the FY 2001/02. So, the comparison of financial performance of commercial banks each other is only possible only the FY 2000/01 onward. ${ }^{1}$ Most of the commercial banks have yet to hold the annual general meeting and publish their annual report for the FY 2004/05. So, it is not possible to include this FY in the study. Therefore, this study covers the last four consecutive fiscal years-from the FY 2000/01 through FY 2003/04.

The analysis of this study is entirely based on the CAMELS framework. As stated in theoretical prescription, health check up of any FIs in this framework is concentrated in the six components: capital adequacy, asset quality, management quality, earning, liquidity and sensitivity to market. But in this study, the last component has been dropped due to the presence of much more complication. So, analysis of financial health of joint venture banks is carried out in the framework of CAMEL. Indicators of each component also have been used according to the financial data disclosed in annual reports of sampled joint venture banks. So, complicated indicators of each component of CAMEL framework of checking up the health of the banks have been skipped up in this study (for the indicators of each component refer to Appendix 2).

\section{Analysis of Financial Health of Commercial Banks}

This section of this paper analyses the indicators of the financial health of sampled joint venture banks in the CAMEL framework. As stated in methodology, all indicators of the financial health of FIs have not be worked out and analyzed, only the indicators permitted by the publicly available comparable financial data have been used to analyze the financial health of the sampled banks. The ensuing section presents the analysis of different indicators of sound health of an FI in the context of joint venture banks in Nepal.

\subsection{Capital Adequacy}

As stated earlier, leverage ratio, core capital ratio, total capital ratio and supplementary capital ratio are used as the indicators of capital adequacy of an FI. Leverage ratios of sampled banks, in general, show that joint venture banks are well capitalized and they are strong enough to mange the shock to balance sheet. Since the leverage ratios of sampled banks during the study periods are greater than 5 percent. Conventionally, leverage ratio of 5 percent or greater than 5 percent indicates that commercial banks are well capitalized. The indicators: TCR, CCR and SCR, of capital adequacy of joint venture banks also corroborate with the implication of leverage ratio. In general, all banks under study have met the capital adequacy ratio as directed by NRB. Only NSBI has not met the minimum capital requirement as directed by NRB in the FY 2000/01 and FY 2003/04. In these fiscal years, its TCR and CCR are lower than that of minimum ratio specified by NRB. Similarly, in the

Financial information for the FY2000/01 were extracted from the annual reports of the sample banks. But this was not possible in Nabil Bank Ltd. 
FY 2003/04, its TCR is slightly lower than that of ratio as per the directive of NRB.

Table 1: Indicators of Capital Adequacy of Sampled Banks

\begin{tabular}{|c|c|c|c|c|c|c|c|c|}
\hline \multirow{2}{*}{$\begin{array}{l}\text { Fiscal } \\
\text { Year }\end{array}$} & \multirow[t]{2}{*}{ Bank } & \multicolumn{2}{|c|}{ TCR (in \%) } & \multicolumn{2}{|c|}{ CCR (in \%) } & \multirow{2}{*}{$\begin{array}{l}\text { LRO } \\
(\text { in } \%)\end{array}$} & \multicolumn{2}{|c|}{ SCR (in \%) } \\
\hline & & $\overline{\mathrm{TCR}_{\mathrm{o}}}$ & $\mathrm{TCR}_{\text {Miin }}$ & $\mathrm{CCR}_{\mathrm{o}}$ & $\mathrm{CCR}_{\text {Miin }}$ & & $\mathrm{SCR}_{\mathrm{o}}$ & $\mathrm{SCR}_{\text {Max }}$ \\
\hline \multirow{4}{*}{2001} & Nabil & 10.46 & 9.00 & 6.50 & 4.50 & 5.81 & 3.96 & 6.50 \\
\hline & NSBI & 5.49 & 9.00 & 4.45 & 4.50 & 3.28 & 1.04 & 4.45 \\
\hline & SCBN & 14.00 & 9.00 & 11.61 & 4.50 & 5.42 & 2.39 & 11.61 \\
\hline & $\mathrm{IAR}^{* *}$ & 11.18 & & & & & & \\
\hline \multirow{5}{*}{2002} & Nabil & 13.86 & 9.00 & 10.53 & 4.50 & 8.31 & 3.33 & 10.53 \\
\hline & NSBI & 12.86 & 9.00 & 10.83 & 4.50 & 7.83 & 2.03 & 10.83 \\
\hline & SCBN & 17.39 & 9.00 & 13.92 & 4.50 & 6.23 & 3.49 & 13.92 \\
\hline & IAR* & 13.82 & & & & & & \\
\hline & Nabil & 13.06 & 10.00 & 11.46 & 5.00 & 8.79 & 1.60 & 11.46 \\
\hline \multirow[t]{4}{*}{2003} & NSBI & 12.34 & 10.00 & 10.16 & 5.00 & 7.46 & 2.19 & 10.16 \\
\hline & SCBN & 14.21 & 10.00 & 12.31 & 5.50 & 6.04 & 1.90 & 12.31 \\
\hline & IAR* & 11.95 & & & & & & \\
\hline & Nabil & 13.56 & 11.00 & 12.12 & 5.50 & 9.61 & 1.43 & 12.12 \\
\hline \multirow[t]{3}{*}{2004} & NSBI & 10.95 & 11.00 & 9.47 & 5.50 & 7.36 & 1.47 & 9.47 \\
\hline & SCBN & 15.57 & 11.00 & 13.76 & 5.50 & 5.83 & 1.81 & 13.76 \\
\hline & IAR* $^{*}$ & 11.62 & & & & & & \\
\hline
\end{tabular}

Source: Worked out from the data extracted from annual reports of sampled banks.

*NRB, Annual Bank Supervision Report, 2003-2004, p.35

** NRB, Banking Supervision Annual Report, 2001-2002, p.25.

Capital of commercial banks in Nepal is negative due to the heavy amount of negative capital of two public sector banks: Nepal Bank Ltd. and Rastriya Banijya Bank. Capital of these two banks is negative due to the heavy accumulated losses. Thus, the public sector banks have yet to meet the capital adequacy requirements as required by NRB. But private sector banks have, in general, met the capital adequacy requirement. The comparison between the capital fund to risk weighted assets ratio of each individual joint venture bank with the aggregate capital fund ratio of private sector commercial banks (IAR) implies that joint venture banks have stronger capital base than that of other private sector banks in general. In addition, average capital fund ratio of joint venture banks during the study period hovers around 14 percent. This is higher than the minimum ratio specified by NRB. This clearly implies that joint venture banks are complying with the directive of NRB on the requirement of the capital base of commercial banks.

As stated in the foregoing analysis, banks under study are well capitalized and they are complying with the directive of NRB on capital adequacy ratio. But their capital base relative to the risk weighted assets is not so strong. According to the international rating convention, total capital should be greater than 19.5 percent of the total risk weighted assets of commercial banks in order to be a strong capital base. But none of the banks under study has the capital fund greater than 19.5 percent of the total risk weighted capital. As indicated by TCR, on the average, capital adequacy of joint venture banks is fair during the study period. Total capital adequacy ratio less than 15 and equal to 12 indicates that capital adequacy is fair and on the average this ratio falls within this range. 


\subsection{Asset Quality}

It is obvious from the theoretical prescription that the health of commercial banks largely depends on the quality of assets held by them, and quality of the assets relies on the financial health of their borrowers. As stated earlier, many indicators can be used to measure the quality of assets held by commercial banks. But, here, only two simple indicatorsnon-performing asset ratio and loan loss reserve ratio-are used to measure the quality of assets being held by banks. The increasing trend of these ratios shows the deteriorating quality of commercial bank assets. In general, 5 percent to 10 percent of non-performing assets is considered as satisfactory level of quality of bank assets,

Table 2: Indicators of Asset Quality of Sampled Banks

\begin{tabular}{|c|c|c|c|c|c|c|}
\hline \multirow[b]{2}{*}{ FY } & & TLA & NPA & LLR & NPAR & LLRR \\
\hline & Bank & (in Million) & (in Million) & (in Million) & (in \%) & (in \%) \\
\hline \multirow{4}{*}{2001} & Nabil & 7732.637 & 1237.995 & NA & 16.01 & NA \\
\hline & NSBI & 4188.414 & 483.388 & 242.849 & 11.54 & 5.80 \\
\hline & SCBN & 5681.532 & 297.231 & 274.260 & 5.23 & 4.83 \\
\hline & IAR $^{*}$ & & & & 29.31 & 18.55 \\
\hline \multirow{4}{*}{2002} & Nabil & 7801.849 & 556.878 & 363.954 & 7.14 & 4.66 \\
\hline & NSBI & 4584.395 & 289.766 & 285.146 & 6.32 & 6.22 \\
\hline & SCBN & 5696.182 & 275.934 & 332.177 & 4.84 & 5.83 \\
\hline & IAR $^{*}$ & & & & 30.41 & 26.62 \\
\hline \multirow{4}{*}{2003} & Nabil & 8113.684 & 449.631 & 357.732 & 5.54 & 4.41 \\
\hline & NSBI & 4795.837 & 426.947 & 327.117 & 8.90 & 6.82 \\
\hline & SCBN & 6000.163 & 247.959 & 304.339 & 4.13 & 5.07 \\
\hline & IAR* $^{*}$ & & & & 28.68 & 25.95 \\
\hline \multirow{3}{*}{2004} & Nabil & 8548.657 & 286.679 & 358.664 & 3.35 & 4.20 \\
\hline & NSBI & 5531.834 & 345.821 & 388.172 & 6.25 & 7.02 \\
\hline & SCBN & 6693.862 & 252.198 & 283.620 & 3.77 & 4.24 \\
\hline IAR* & & 22. & 22.13 & & & \\
\hline
\end{tabular}

Source: Worked out from the data extracted from annual reports of sampled banks.

*NRB, Annual Bank Supervision Report, 2003-2004, pp.39-40.

Percent of non-performing assets of commercial banks as a whole tends to decrease in the latter fiscal years, but still they are not satisfactory. The unsatisfactory level of nonperforming assets in the total assets of the commercial banks as a whole is mainly due to the high percent of non-performing assets of two public sector banks-Nepal Bank Ltd. and Rastriya Banijya Bank. Though HMG/Nepal has contracted out the management of these banks, it has not been able to bring down the percent of non-performing assets of these banks. In the FY 2003/04, nonperforming assets of Rastriya Banijya Bank was 57.64 percent and in the case of Nepal Bank Ltd., it was 53.74 percent (NRB 2005).

Nonperforming assets of joint venture banks on the average is at satisfactory level, but they are far below the aggregate percentage of nonperforming assets of commercial banks. Both NPAR and LLRR indictors show that joint venture banks are improving the quality of their assets year by year. Overall, both NPAR and LLRR imply the sound financial health of the joint venture banks. 


\section{3 Management Quality}

Sound management is key to the performance of any organizations but is difficult to measure. It is primarily a qualitative factor applicable to individual institutions. As discussed earlier, several indicators can jointly serve as an indicator of management soundness. However, only operating expenses ratio (OER) and earning per employee (EPE) are used to indicate the quality of management here.

Table 3: Indicators of Management Efficiency of Sampled Banks

\begin{tabular}{|c|c|c|c|c|c|c|c|}
\hline \multirow[t]{2}{*}{ Year } & \multirow[t]{2}{*}{ Bank } & TOR & TOE & NOI & $\mathrm{NOE}$ & OER & EPE \\
\hline & & (in Million) & (in Million) & (in Million) & & $(\%)$ & (in Million) \\
\hline \multirow{4}{*}{2001} & Nabil & 1538.341 & 1014.282 & 524.059 & 388 & 65.93 & 1.3507 \\
\hline & NSBI & 506.837 & 450.934 & 55.903 & 135 & 88.97 & 0.4141 \\
\hline & SCBN & 1662.084 & 902.691 & 759.393 & 256 & 54.31 & 2.9664 \\
\hline & IAR** & 8841.000 & 5418.000 & 3423.000 & $\overline{\mathrm{NA}}$ & 61.28 & NA \\
\hline \multirow{4}{*}{2002} & Nabil & 1639.315 & 1185.360 & 453.955 & 382 & 72.31 & 1.1884 \\
\hline & NSBI & 508.373 & 443.528 & 64.845 & 141 & 87.24 & 0.4599 \\
\hline & SCBN & 1446.815 & 692.869 & 753.946 & 243 & 47.89 & 3.1027 \\
\hline & IAR* $^{*}$ & 8283.876 & 5340.450 & 2943.426 & NA & 64.47 & NA \\
\hline \multirow{5}{*}{2003} & Nabil & 1340.504 & 745.705 & 594.799 & 326 & 55.63 & 1.8245 \\
\hline & NSBI & 565.908 & 487.089 & 78.819 & 148 & 86.07 & 0.5326 \\
\hline & SCBN & 1503.602 & 696.834 & 806.768 & 275 & 46.34 & 2.9337 \\
\hline & $\mathrm{IAR}^{*}$ & 9201.407 & 5808.051 & 3393.356 & NA & 63.12 & NA \\
\hline & Nabil & 1333.655 & 697.421 & 636.234 & 372 & 52.29 & $\overline{1.7103}$ \\
\hline \multirow[t]{3}{*}{2004} & NSBI & 611.607 & 480.169 & 131.438 & 151 & 78.51 & 0.8705 \\
\hline & SCBN & 1584.008 & 713.705 & 870.303 & 263 & 45.06 & 3.3091 \\
\hline & IAR* & 10621.295 & 6387.665 & 4233.630 & NA & 60.14 & NA \\
\hline
\end{tabular}

Source: Worked out from the data extracted from annual reports of sampled banks.

*NRB, Annual Bank Supervision Report, 2003-2004, p.41.

**NRB, Banking Supervision Annual Report 2001-2002, p.28.

Public sector banks in Nepal are constantly sustaining the loss during the study period. However, the private sector banks are earning the operating profit during the observed period. Here, for comparison purpose, overall operating expenses ratios of private sector banks have been taken as industry average ratio (IAR). Both OER and EPE indicate that NSBI management is the least efficient among the sampled joint venture banks, SCBN management is the most efficient among the sampled banks, and Nabil is the mediocre. But relative to the industry average, performance of management of joint venture banks is satisfactory. Overall, indicators of management efficiency show relatively healthy joint venture banks in Nepal.

\subsection{Earnings}

Earning capacity largely counts on the efficiency of management. Chronically, loss making commercial banks reduce their capital base, risk the solvency and eventually bring down the wealth of their shareholders. Conversely, constantly profit making banks add equity to the total capital fund, reduce the risk of insolvency, and finally increase the wealth of their shareholders. So, earning capacity is one of the indicators of the sound health of a commercial bank. Though different indicators can be used to measure the profitability of 
banks, ROE, ROA and PM are used in this study. Profitability of commercial banking industry in Nepal is constantly sustaining the operating loss due to the heavy loss incurred by two public sector banks during the study period. Inclusion of these two banks in calculation of industry average ratio distorts the interpretation of the profitability of the commercial banking industry. So, public sector banks have been excluded from the industry average ratio.

ROE, ROA and PM show that profitability of joint venture bank is not so weak during the study period. Profitability of Nabil, SCBN is better than the industry average but the earning capacity of NSBI is below the industry average in all observed FYs. On the average, earning performance of joint venture banks, as indicated by ROA, is fair. As per the conventional rules, ROA of commercial banks should fall in the range of less than 3 and equal to 2 in order to be satisfactory earning performance. But only SCBN has the ROA greater than 2 in all study years. Profitability indicators of NSBI show that relative to other commercial banks it is weak in earning performance during the study period. Its ROA in all observed FYs is below one. As per the conventional rule of rating, the commercial banks having the ROA less than 1 fall in the marginal earning performance zone. So, earning performance of NSBI is marginal during the study period.

Table 4: Indicators of Earning Capacity of Sampled Banks

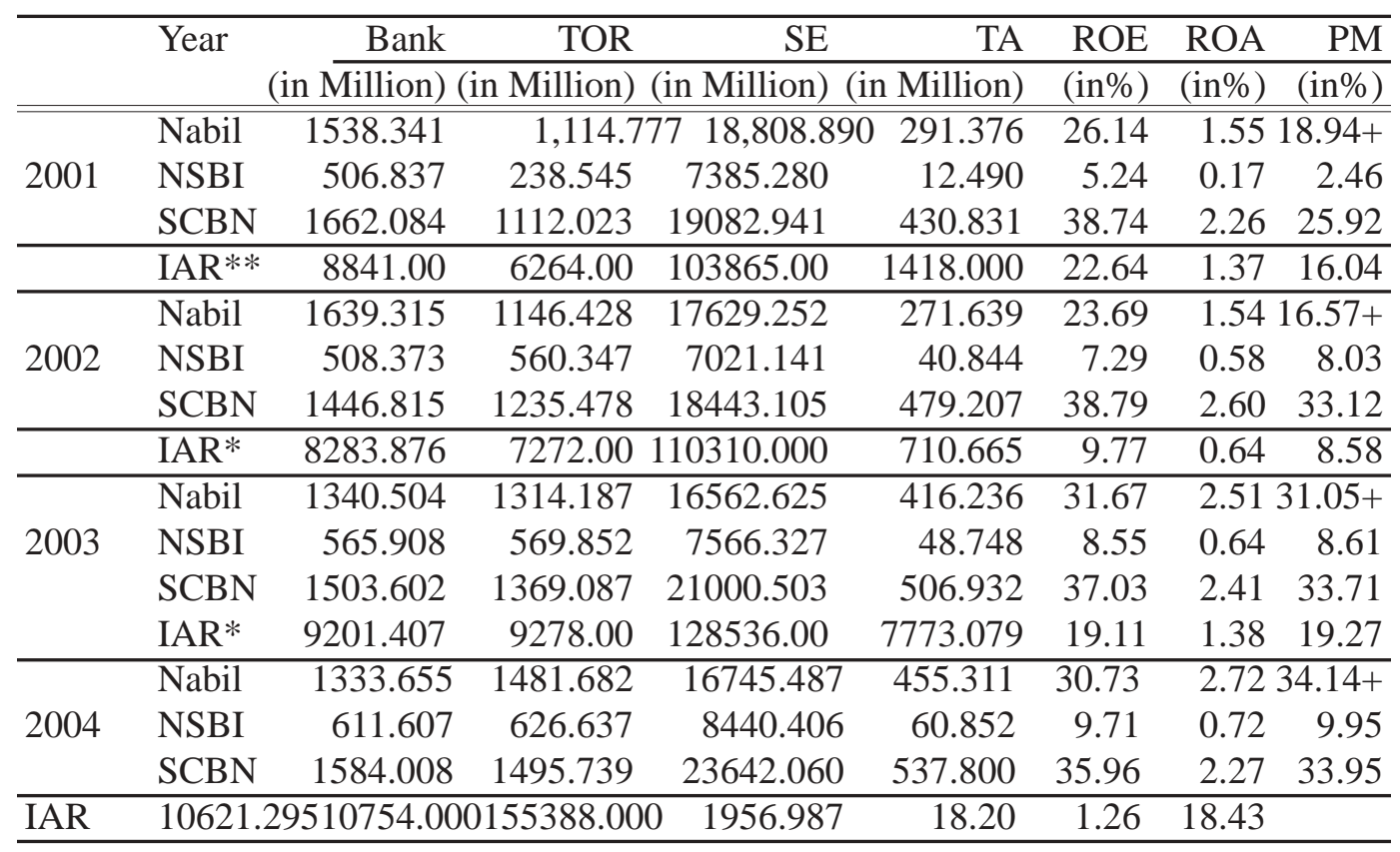

Source: Worked out from the data extracted from annual reports of sampled banks.

*NRB, Annual Bank Supervision Report, 2003-2004, p.41.

**NRB, Banking Supervision Annual Report 2001-2002, p.28.

+The PMs given in the annual reports differ from the calculated PMs due to the inclusion of nonoperating revenue in the operating revenue. 


\subsection{Liquidity Position}

Bank should have ready access to immediately spendable funds at reasonable cost at precisely the time those funds are needed. Lack of adequate liquidity is often one of the first signs that a bank is in serious financial trouble (Rose 1999). Bank should have adequate liquidity to minimize both asset side liquidity risk and liability side liquidity risk of a commercial bank. Both liquidity deficit and much more liquidity surplus indicate the problem in the financial health of a commercial bank. Much more liquidity surplus hurts the profitability of the commercial bank by reducing the return on assets. Similarly, liquid deficit also costs much to the commercial banks in term of the higher purchasing price of liquidity and hurt in the reputation of the banks. Therefore, commercial banks should strike the trade-off between the profitability and liquidity risk.

As stated earlier in theoretical prescription, NRB uses total loan to total deposit ratio (LDR), cash and equivalents to total assets ratio (CETAR), cash and equivalents to total deposit ratio (CETDR), and cash balance with NRB to total deposit ratio (CBNRBR) to measure the liquidity position of commercial banks. LDR of commercial banking industry as whole is not so high. It hovers in the range of 50 percent to 64.59 percent of the total deposit. This implies that commercial banks are not heavily relying on the short-term money market and they will not face the liquidity problems in future. Other two indicators-CETAR and CETDR - also show the high liquidity position of commercial banks. Relative to the other joint venture banks, NSBI has high liquidity and low profitability during the study period. On the whole liquidity position of joint venture banks is higher than the industry average ratio.

Table 5: Indicators of Liquidity Position of Sampled Banks

\begin{tabular}{rlrrrr}
\hline Year & Bank & $\begin{array}{r}\text { LDR } \\
\text { (in \%) }\end{array}$ & $\begin{array}{r}\text { CETAR } \\
\text { (in \%) }\end{array}$ & $\begin{array}{r}\text { CETDR } \\
\text { (in \%) }\end{array}$ & $\begin{array}{r}\text { CBNRBR } \\
\text { (in \%) }\end{array}$ \\
\hline \hline \multirow{2}{*}{2001} & Nabil & 50.47 & 7.10 & 8.43 & 3.23 \\
& NSBI & 63.34 & 32.70 & 34.98 & 4.58 \\
& SCBN & 36.82 & 18.72 & 23.16 & 4.25 \\
& IAR** & 59.00 & 19.01 & 22.18 & 12.50 \\
\hline \multirow{2}{*}{2002} & Nabil & 50.31 & 6.14 & 6.99 & 3.27 \\
& NSBI & 82.27 & 23.07 & 29.07 & 21.13 \\
& SCBN & 35.97 & 15.65 & 18.23 & 2.38 \\
& IAR* & 61.62 & 12.13 & 14.50 & 13.40 \\
\hline \multirow{2}{*}{2003} & Nabil & 60.34 & 10.96 & 13.50 & 6.64 \\
& NSBI & 73.52 & 17.62 & 20.44 & 13.71 \\
& SCBN & 31.99 & 15.10 & 16.90 & 2.73 \\
& IAR* & 62.84 & 11.53 & 13.87 & 8.90 \\
\hline \multirow{2}{*}{2004} & Nabil & 60.55 & 11.28 & 13.38 & 8.08 \\
& NSBI & 76.85 & 10.24 & 12.01 & 8.06 \\
& SCBN & 31.63 & 17.94 & 20.04 & 7.25 \\
& IAR* & 64.59 & 11.73 & 14.01 & 9.40 \\
\hline
\end{tabular}

Source: Worked out from the data extracted from annual reports of sampled banks.

*NRB, Annual Bank Supervision Report, 2003-2004, p.31.

**NRB, Banking Supervision Annual Report 2001-2002, p.18. 
As directed by NRB, commercial banks had to maintain 3 percent cash of the total deposits in their vault in the FY 2001 and 2002, and 2 percent in the FY 2003 (NRB 2003a). NRB withdrew the provision of maintaining 2.0 percent balance in commercial banks' vault as part of CRR (NRB 2004). In spite of the withdrawal of this provision, level of liquid assets of commercial banks, on the average, is higher than the industry average ratio during the study period. But none of the banks has met the mandatory level of cash reserve ratio in all fiscal years. Joint venture banks under study have complied with the CRR provision only in the latter two years. Relative to other two banks, NSBI has high ratio of cash balance with NRB. On the whole, CBNRBR of joint venture banks is less than that of the industry average ratio during the study period but CETDR is greater than that of industry average ratio.

\section{Diagnoses}

5.1 Joint venture commercial banks are well capitalized but their capital base relative to the risk weighted assets is not strong. According to the international convention of rating, their capital base is fair. This implies that their financial health is not so strong to manage the strong balance sheet shocks.

5.2 Quality of assets of joint venture banks on the average is satisfactory. Nonperforming assets of all joint venture banks under study are far below the aggregate percentage of nonperforming assets of commercial banks. Both NPAR and LLRR show that joint venture banks are improving the quality of their assets year by year. On the whole, both NPAR and LLRR imply the sound financial health of the joint venture banks.

5.3 Both indicators - operating expenses ratio and earning per employee_of management quality of joint venture banks are above the industry average during the study period. So, relative to the industry average, performance of management of joint venture banks is satisfactory. On the whole, indicators of management efficiency show relatively healthy joint venture banks in Nepal.

5.4 Earning/profitability indicators - ROE, ROA and PM-show that financial health of joint venture banks is not so weak. In general, earning performance of joint venture banks, as indicated by ROA, is fair. But the financial health, as implied by profitability indicators, of NSBI is weaker than that of other joint venture banks.

5.5 Liquidity indicators of joint venture banks show that they have stored high level of liquidity and are not facing the liquidity deficit problem, instead, they are facing the high liquidity problem. Their high liquidity is affecting their financial health adversely by deteriorating their profitability. Thus, with a view point of liquidity position, the health of joint venture banks is looked like a little bit unhealthy. 
Appendix 1: List of Commercial Banks, Population Frame and Sample

\begin{tabular}{clc}
\hline S.N. & \multicolumn{1}{c}{ Name of the Banks } & Incorporated Year in A.D + \\
\hline 1 & Nepal Bank Ltd. & 1937 \\
2 & Rastriya Banijya Bank Ltd. & 1966 \\
3 & NABIL Bank Ltd. \# * & 1984 \\
4 & Nepal Investment Bank Ltd. & 1986 \\
5 & Standard Chartered Bank Ltd. \#* & 1987 \\
6 & Himalayan Bank Ltd. \#* & 1993 \\
7 & Nepal SBI Bank Ltd. \# * & 1993 \\
8 & Nepal Bangladesh Bank Ltd. \# $*$ & 1993 \\
9 & Everest Bank Ltd. \#* & 1994 \\
10 & Bank of Kathmandu Ltd. & 1995 \\
11 & Nepal Credit and Commerce Bank Ltd. & 1996 \\
12 & Lumbini Bank Ltd. & 1998 \\
13 & NIC Bank Ltd. & 1998 \\
14 & Machhapuchre Bank Ltd. & 2000 \\
15 & Kumari Bank Ltd. & 1999 \\
16 & Laxmi Bank Ltd. & 2001 \\
17 & Siddhartha Bank Ltd. & 2001 \\
\hline
\end{tabular}

Sources: NRB. Banking and Financial Statistics 44 (Mid-January 2005) : 45.

+ Nepalese calendar date has been converted into Gregorian date.

\# Population of the Study

*Sample of the Study

\section{Appendix 2: Indicators of Each Components of CAMEL Framework}

\section{Capital Adequacy}

1.1 Leverage Ratio (LR)

$$
\mathrm{LR}=\frac{C C}{T A}
$$

Where

$\mathrm{CC}=$ core capital

$\mathrm{TA}=$ total assets

\subsection{Core Capital Ratio (CCR)}

$$
\mathrm{CCR}=\frac{C C}{R W A}
$$

Where

RWA =risk weighted assets

\subsection{Total Capital Ratio (TCR)}

$\mathrm{TCR}=\frac{T C}{R W A}$

Where

$\mathrm{TC}=$ total capital (core capital plus supplementary capital) 


\subsection{Supplementary Capital Ratio (SCR)}

$\mathrm{SCR}=\frac{S C}{R W A}$

Where

$\mathrm{SC}=$ supplementary capital

\section{Assets Quality}

2.1 Nonperforming Loan Ratio (NPAR)

NPAR $=\frac{N P A}{T L A}$

Where

NPA $=$ nonperforming assets (loan and advance)

TLA $=$ total loan and advance

2.2 Loan Loss Reserve Ratio (LLRR)

LLRR $=\frac{L L R}{T L A}$

Where

LLR $=$ loan loss reserve

3. Management Efficiency

3.1 Operating Expenses Ratio (OER)

$\mathrm{OER}=\frac{T O E}{T O R}$

Where

TOE $=$ total operating expenses, and it includes interest expenses, employees expenses, office operating expenses, currency exchange loss, bad loan advance written off and loan loss provision.

TOR $=$ total operating revenue, and it includes interest income and non-interest income.

3.2 Earning per Employee (EPE)

$\mathrm{EPE}=\frac{N O I}{N O E}$

Where

$\mathrm{NOI}=$ net operating income

$\mathrm{NOE}=$ number of employees

4. Earning Performance

4.1 Return on Equity (ROE)

$\mathrm{ROE}=\frac{N I}{S E}$

Where

$\mathrm{NI}=$ net income

$\mathrm{SE}=$ shareholder equity 
4.2 Return on Assets (ROA)

$\mathrm{ROA}=\frac{N I}{T A}$

Where

$\mathrm{TA}=$ total assets

4.3 Profit Margin (PM)

$\mathrm{PM}=\frac{N I}{T O R} \quad \ldots \quad \ldots \quad \ldots$

\section{Liquidity Position}

5.1 Loan to Deposit Ratio (LDR)

$\mathrm{LDR}=\frac{T L A}{T D}$

Where

TLA = total loan and advance (before deduction of loan loss reserve)

$\mathrm{TD}=$ total deposit

5.2 Cash and Equivalent to Total Asset Ratio (CETAR)

CETAR $=\frac{C E}{T A}$

5.3 Cash and Equivalent to Total Deposit (CETDR)

CETDR $=\frac{C E}{T D}$

5.4 Cash Balance with NRB to Total Deposit Ratio (CBNRBR)

$\mathrm{CBNRBR}=\frac{C B N R B}{T D} \quad \ldots \quad \ldots \quad \ldots$ (5.4)

Where

$\mathrm{CBNRB}=$ cash balance with NRB

\section{REFERENCES}

ADB. 2002.Guidelines for the Financial Governance and Management of Investment Projects Financed by the ADB. Manila: ADB.

Evan, Owns and others. 2000. "Macroprudential Indicators of Financial System Soundness." Occasional Paper 192. Washington DC: International Monetary Fund.

Gilbert, R. Alton, Andrew P. Meyer and Mark D.Vaughan. 2000. "The Role of a CAMEL Downgrade Model in Bank Surveillance." Working Paper 2000-021A, The Federal Reserve Bank of St. Louis. Nov. 1, 2005 ( http://research.stlouisfed.org/wp/2000/2000-021.pdf).

Hilbers, Paul, Russell Krueger, and Marina Moretti. 2000. New Tools for Assessing Financial System Soundness. Finance and Development $37: 8-12$

McNally, EdwardA.. 1996. "Basic Topics in Sound Bank Management." EDI Working Paper, Washington DC: The World Bank.

NRB (NRB). 2005. Annual Bank Supervision Report, 2003-2004. Kathmandu: NRB, Bank Supervision Department, Central Office.

-- --. 2005. Annual Report, 2003/2004. Kathmandu: NRB.

-- -- -. 2005. Directive Number 1/20061/62. Kathmandu: Banking Supervision Division, NRB.

-- --. 2005. Directive Number 3/20061/62. Kathmandu: Banking Supervision Division, NRB.

-- ---. 2003. Banking Supervision Annual Report, 2001/02. Bank Supervision Department, NRB.

-- -- --. 2003a. Monetary Policy and Programs for FY2002/03. Kathmandu: NRB.

-- --. 2004. Monetary Policy for FY2004/05. Kathmandu: NRB .

-- -- -. 2058. Directives to All Commercial Banks. Kathmandu: Bank Management Division, NRB.

Rose, Peter S. 1999. Commercial Bank Management, 4rth ed. Boston: Irwin McGraw-Hill.

Saunders, Anthony and Marcia Millon Cornett. 2004. Financial Markets and Institutions. New Delhi: Tata McGraw-Hill Publishing Company Limited. 